\title{
The Blood Libel and the Leper Libel: Ancient Antisemitism?
}

Was there a "Jewish problem" in antiquity? ${ }^{1}$ Did Jews make themselves sufficiently offensive to generate resentment, fear, or hostility? Or, regardless of Jewish actions or intentions, were they perceived as distasteful, objectionable, or dangerous? Discussions of antisemitism in the Greco-Roman world are legion, and the bibliography seems to grow monthly. I make no effort to summarize it all, let alone to engage with any of it in detail in the short space available. Nor will I endeavor to construct a definition of "antisemitism" which would inevitably be arbitrary, disputable, and probably unhelpful. One can, of course, always resort to the comfortable evasion of saying what was said of pornography, "I can't define it but I know it when I see it." On any reckoning, Jews, at least those in the diaspora, were outside the mainstream, usually marginal, and often separatist. That could get them into trouble on occasion, for they were conspicuous, conspicuously different, and, in the event of turbulent circumstances, vulnerable.

Scholarship on the subject, which began as early as the eighteenth century, featured by luminaries like Johann Gustav Droysen, Theodor Mommsen, Eduard Meyer, and Elias Bickerman, has labored mightily to identify reasons why gentiles might have found Jews to be odious or menacing. ${ }^{2}$ The most common reasons postulated by researchers are the social non-conformism of the Jews, their supposed shunning of the majority culture, their isolationism which slid into xenophobia and misanthropy, their monotheism that scorned civic cults, not to mention emperor worship, their peculiar customs like circumcision, dietary laws, and observance of the Sabbath that pagans found especially bizarre and subject to mockery, their religious beliefs that set them apart from the rest of society, their claim to be a chosen people, their proselytism that threatened the coherence and stability of traditional Greco-Roman values, indeed their fundamental ethnocentricity which, as the influential Israeli scholar Victor Tcherikover put it a generation ago, made their very existence a foreign body among other peo-

1 See A. S. Lindemann, “The Jewish Question," in Antisemitism: A History, ed. A. S. Lindemann and R. S. Levy (Oxford: Oxford University Press, 2010), 17-33. W. Schmitthenner, "Kennt die hellenistisch-römische Antike eine Judenfrage?” in Die Juden als Minderheit in der Geschichte, ed. B. Martin and E. Schulin (Munich: Dt. Taschenbuch Verlag, 1981), 9-29, questions the applicability of the term to the Jews of classical antiquity.

2 See the excellent study of C. Hoffmann, Juden und Judentum im Werk deutscher Althistoriker des 19. und 20. Jahrhunderts (Brill: Leiden, 1988).

Ә OpenAccess. () 2021 Erich S. Gruen, published by De Gruyter. (cc))BY-NC-ND This work is licensed under the Creative Commons Attribution-NonCommercial-NoDerivatives 4.0 International License. 
ples. These have loomed as the principal elements identified by scholars as grounds for the animosity toward Jews that manifests itself in classical literature. ${ }^{3}$ Some moderns, however, have questioned the extent of Judenhass in the pagan world or sought to balance pro- and anti-Jewish sentiments in the surviving texts. ${ }^{4}$

A brief study cannot possibly profess to resolve the larger problem of whether or how far antisemitism played a role in the perceptions of Jews by Greeks and Romans. It represents only a step in that direction but a not insignificant one. This essay looks at perhaps the two most celebrated or notorious slanders perpetrated by pagans on the Jews and seeks to deconstruct their implications and their reverberations. The first is the so-called blood libel, the allegation that Jews indulged in the practice of sacrificing human victims to their god, even engaging in ritual cannibalism. That accusation, ostensibly initiated in antiquity, proceeded to haunt Jews as a toxic smear throughout much of the Middle Ages and beyond. ${ }^{5}$ The second is what one might call the leper libel. It refers to

3 The scholarship on this subject is vast and cannot possibly be summarized here. Among the more important contributions in recent decades are R. R. Ruether, Faith and Fratricide: The Theological Roots of Anti-Semitism (New York: Seabury, 1974); J. N. Sevenster, The Roots of Pagan AntiSemitism in the Ancient World (Leiden: Brill, 1975); J. L. Daniel, "Anti-Semitism in the HellenisticRoman Period,” Journal of Biblical Literature 98 (1979): 45-65; N. de Lange, “The Origins of AntiSemitism: Ancient Evidence and Modern Interpretations," in Anti-Semitism in Times of Crisis, ed. S. L. Gilman and S. T. Katz (New York: New York University Press, 1991), 21-37; J. G. Gager, The Origins of Anti-Semitism (Oxford: Oxford University Press, 1983); L. H. Feldman, Jew and Gentile in the Ancient World (Princeton: Princeton University Press, 1993); Z. Yavetz, "Judeophobia in Classical Antiquity: A Different Approach,” Journal of Jewish Studies 44 (1993): 1-22; P. Schäfer, Judeophobia: Attitudes Toward the Jews in the Ancient World (Cambridge: Harvard University Press, 1993); B. Isaac, The Invention of Racism in Classical Antiquity (Princeton: Princeton University Press, 2004), 440 - 91; D. Nirenberg, Anti-Judaism: The Western Tradition (New York: Norton, 2013), 13-47. On Tcherikover, see D. R. Schwartz, "Antisemitism and Other-isms in the Greco-Roman World," in Demonizing the Other: Antisemitism, Racism, and Xenophobia, ed. R. S. Wistrich (Amsterdam: Harwood Academic, 1999), 73-75.

4 See, e.g., Ruether, Faith and Fratricide; Gager, Origins of Anti-Semitism, 39-88; L. H. Feldman, "Pro-Jewish Intimations in Anti-Jewish Remarks Cited in Josephus' Against Apion," Jewish Quarterly Review 78 (1988): 187-251; Feldman, Jew and Gentile, 84-287; E. S. Gruen, "Was There Judeophobia in Classical Antiquity," in Constructs of Identity in Hellenistic Judaism: Essays on Early Jewish Literature (Berlin: De Gruyter, 2016), 313-32.

5 On the subsequent history of the blood libel, see G. I. Langmuir, Toward a Definition of Antisemitism (Berkeley: University of California Press, 1990), 263-81; D. Biale, Blood and Belief: The Circulation of a Symbol between Jews and Christians (Berkeley: University of California Press, 2007), 111-17; J. Cohen, “The Blood Libel in Solomon Ibn Verga's Shevet Yehudah," in Jewish Blood: Reality and Metaphor in History, Religion, and Culture, ed. M. B. Hart (New York: Routledge, 2009), 116-35; Nirenberg, Anti-Judaism, 202-7. 
the notion that the origins of the nation did not derive from a bold exodus from Egypt by heroic rebels who thwarted the Egyptian oppressors and went on to settle the promised land but from ignominious flight by a bunch of wretched lepers and purveyors of disease who were expelled from Egypt as a scourge and proceeded to ravage and plunder wherever they could. That defamatory story, in various versions, found echoes in a number of narratives by Egyptian, Greek, or Roman writers. To what degree did the mud-slinging exemplified by these two slanders actually stick? ${ }^{6}$

I

The idea that Jews practiced human sacrifice first surfaces in a most unlikely source: the fourth-century B.C.E. Greek philosopher and most famous pupil of Aristotle, Theophrastus. The relevant passage is puzzling and provocative. It comes to us secondhand, from a treatise On Piety composed by Theophrastus but transmitted by the Neoplatonist Porphyry more than five centuries later. ${ }^{7}$ That is not very reassuring. The quotation, if accurate, has Theophrastus say that the Syrians, of whom Jews were a part, sacrifice live victims. They do not eat them but burn them whole at night, pour honey and wine on them, and quickly destroy them, lest they be seen by day. They fast in the course of it, and, he adds, they were the first to conduct sacrifices both of animals and of themselves, thus evidently of other human beings. ${ }^{8}$ How telling a claim was this? The passage is packed with problems.

Theophrastus is evidently not very well informed about Jews. They do not, in fact, eat their sacrificial victims, they don't pour honey on them, they don't burn them at night to avoid being observed, and they don't fast in the performance of the ritual. The reliability of Theophrastus or of the transmission of his text is thus doubtful. And that doubt carries over to the statement about the performance of

6 I omit here a third notorious accusation, the so-called "ass libel," which surfaces in diverse versions as the statue of an ass or the golden head of an ass or a representation of Moses seated on an ass, evidently as an object of worship in the Temple. Not only is the allegation absurd on the face of it, reported only in a few and contradictory stories, but pagans, who themselves made images of their deities, would hardly find this a damaging charge to be levelled against others. On the "ass libel," see now the treatment, with full bibliography, of B. Bar-Kochva, The Image of the Jews in Greek Literature: The Hellenistic Period (Berkeley: University of California Press, 2010), $206-49$.

7 Theophrastus, in Porphyry, De Abstinentia, 2.26 = M. Stern, Greek and Latin Authors on Jews and Judaism (Jerusalem: The Israel Academy of Sciences and Humanities, 1974), 1:10-12.

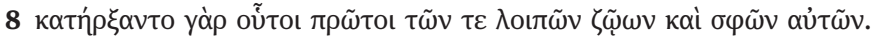


human sacrifice. Why should we believe it? To reconstruct Theophrastus' sources requires pure guesswork. But it appears that the philosopher himself was not fully comfortable with the idea that Jews indulged in human sacrifice. For he adds the statement that they did so under compulsion and not because they had any enthusiasm for it. ${ }^{9}$ Just what kind of compulsion he might have imagined is beyond conjecture. But by tacking on this form of exculpation, Theophrastus signals clearly enough that he is not delivering an antisemitic tirade. That conclusion is reinforced by the fact that in the immediately preceding

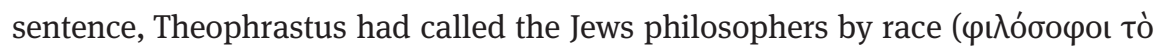
yévos, philosophoi to genos). Coming from a philosopher, that is surely high praise. This does not mean that he was an advocate for Jewish ways or an admirer of the nation, as some have claimed. ${ }^{10}$ But it does take the whole passage out of the category of antisemitic rants. Theophrastus adds that Jews, philosophers as they are, also converse with each other about the deity, observe the stars at night, and call upon god through prayer. The passage is ethnographic rather than polemical. ${ }^{11}$ Reference to human sacrifice may be confusion or an error. ${ }^{12}$ On any reckoning, there is no hint that it served as a blood libel that branded Jews in pagan eyes.

In fact, the charge, in that form, does not recur again in our evidence. In a rather different form, indeed a much more dramatic scenario, it resurfaced, at least in our information, more than four hundred years later. The tale is reported by the Jewish historian Flavius Josephus in his treatise Contra Apionem composed near the end of the first century C.E. That work contains a lengthy defense of Jewish values and accomplishments in response to calumnies (or at least what is represented as calumnies) leveled against them by a variety of Greek and Egyptian writers. A chief target of Josephus' wrath is the learned Homeric scholar, grammarian, and historian Apion, an Alexandrian intellectual steeped in Greek culture, although Josephus seeks to stigmatize him as an Egyptian. ${ }^{13}$

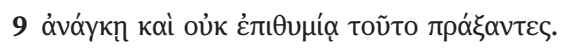

10 So, W. Jaeger, “Greeks and Jews: The First Greek Records of Jewish Religion and Civilization,” Journal of Religion 18 (1938): 137-43; Feldman, Jew and Gentile, 203-4.

11 For the fullest and best discussion of the passage, see Bar-Kochva Image of the Jews, 22-39, with bibliography. His claim, however, that the allusion to human sacrifice was a major negative statement is not justified.

12 It has even been suggested that that the idea arose in Theophrastus' mind because he knew the story in Genesis of the would-be sacrifice of Isaac and he extrapolated from there; Jaeger, "Greeks and Jews," 143. That would be a stretch.

13 On Apion, see the excellent treatment by K. R. Jones, "The Figure of Apion in Josephus' Contra Apionem," Journal for the Study of Judaism 36 (2005): 278-315, with extensive bibliography. Briefer recent discussions by P. W. van der Horst, "Who was Apion?" in Japheth in the Tents of 
Josephus has a number of quarrels with Apion, laced with caustic and barbed vitriol. The most damaging of Apion's hostile aspersions upon Jews is a revival (at least an ostensible revival) of the blood libel.

This time it comes with a narrative, a rather hair-raising one. The tale involves Antiochus IV Epiphanes, a most notorious figure in Jewish history. As ruler of Syria, Antiochus defiled the sacred Temple in Jerusalem, thereby sparking the rebellion of the Maccabees and engendering the holiday of Hanukkah, celebrated ever thereafter. According to Apion, in Josephus' account, Antiochus entered the Temple and discovered a lamentable fellow languishing on a couch, surrounded by heaps of food, fish, fowl, and meat, which the man gawked at in a daze. Once the king entered, the man fell to his knees before him, extended his right hand, and begged to be set free. Antiochus, sympathetic to his plight, asked what was going on, and why he was being plied with gobs of food. The hapless character, weeping and moaning, then poured out the whole story. He identified himself as a Greek who had been kidnapped by foreigners (presumably Jews) and confined to the Temple in Jerusalem, where he had been fattened up by sumptuous meals for almost a full year. That seemed quite hospitable at first, but then he learned about the insidious plan that lay behind it. It was Jewish practice, he was told, to abduct a Greek on a fixed day annually, stuff him with food lavishly for a full year, and then offer him up as a human sacrifice, have a taste of his innards, and, while engaging in the sacrifice, would utter an oath of hostility to Greeks generally, before they took his remains and tossed them in a pit. A pretty grisly tale. This potential victim greeted king Antiochus with enormous relief, stating that only a few days remained in his year before the sacrifice would take place. He called upon Antiochus with a plea to honor the gods of the Greeks and to deliver him from the wicked plots of the Jews that threatened his very lifeblood. ${ }^{14}$

The tale, as we have it, stops there. Whether Apion concluded it at that point or Josephus chose to cut it off we cannot know. In any case, Antiochus Epiphanes, archvillain in Jewish tradition, comes off as a sympathetic character in this story, and any reader would expect him to rescue the corpulent and pitiful victim. Where did this malicious canard come from, and what ends did it serve? Josephus alleges that Apion was a spokesman for others, but he identifies no

Shem: Studies on Jewish Hellenism in Antiquity (Leuven: Peeters, 2002), 207-21, and J. Dillery, "Putting Him Back Together Again: Apion Historian, Apion Grammatikos," Classical Philology 98 (2003): 383-90.

14 Josephus C. Ap. 2.91-96; cf. 2.121. We do not possess the original Greek of Josephus' text here and have to rely on a Latin translation from the sixth century C.E. 
sources here. ${ }^{15}$ He does, however, postulate a motive for the dramatic narrative. The authors of this fanciful fiction, in his view, were apologists for Antiochus IV. They invented this insidious lie in order to clean up the tradition that Antiochus committed perfidy and sacrilege in entering the Temple because his treasury was empty. In short, it was a cover-up. ${ }^{16}$

That explanation has attracted some strong support among modern scholars: the blood libel was manufactured by supporters of Antiochus IV and the regime of the Seleucid kings that he represented. The charge of temple robbery and unlawful penetration into the holy sanctuary needed to be counteracted. Hence propagandists of the Seleucid monarchy fabricated the fiction of the unfortunate Greek and the dastardly deed by bloodthirsty Jews. In this scenario, the depredations by Antiochus in Judea were fully justified. Instead of the wicked oppressor portrayed by the Jews, he came to rescue innocent Greeks victimized by a murderous society. ${ }^{17}$

The theory, however, leaves much to be desired. How likely is it that a Seleucid propaganda machine was revved up to produce a justification for Antiochus' actions in Judea? The king was indeed vilified by the Jews whose Temple he had polluted and whose traditions he had trampled upon. But an apologia would certainly not have been directed to the Jews. Who else would have taken Antiochus' entrance into the Temple amiss? His Seleucid subjects would hardly have blanched at temple robbery or oppression of Jews. And how many would have been mollified by this wildly implausible tale of a Greek fattened up for a year in preparation for slaughter? The details alone would have caused any selfrespecting reader to question the seriousness of this drama. An annual kidnap-

15 Josephus C. Ap. 2.91: propheta vero aliorum factus est Apion. Josephus earlier claimed that Posidonius and Apollonius Molon had supplied Apion with material for his calumnies; $C$. Ap. 2.79. But it is not clear that they are responsible for this tale, and the accuracy of Josephus' citation of them here is itself subject to debate. See J. M. G. Barclay, Flavius Josephus: Against Apion, vol. 10 of Flavius Josephus: Translation and Commentary, ed. S. Mason (Leiden: Brill, 2007), 211-12; Bar-Kochva, Image of the Jews, 441-57, 490-91.

16 Josephus C. Ap. 2.90: volentes enim Antiocho praestare et infidelitatem ac sacrilegium eius tegere, quo circa gentem nostram est usus propter egestatem pecuniarum, detrahentes nobis etiam quae in futuro sunt dicenda mentiti sunt.

17 The classic formulation of this theory is E. Bickerman, "Ritualmord und Eselkult: Ein Beitrag zur Geschichte antiker Publizistik," in Studies in Jewish and Christian History, ed. E. Bickerman (Leiden: Brill, 1980), 238-45. Followed, with variations, by Bar-Kochva, Image of the Jews, 254-59, 271-79. See also J. Rives, "Human Sacrifice Among Pagans and Christians," Journal of Roman Studies 85 (1995): 71. Doubts expressed by Stern, Greek and Latin Authors, 412; Schäfer, Judeophobia, 65; E. S. Gruen, “Greeks and Jews: Mutual Misperceptions in Josephus' Contra Apionem," in Ancient Judaism in its Hellenistic Context, ed. C. Bakhos (Leiden: Brill, 2005), 47; Barclay, Flavius Josephus, 217. 
ping on the same day each year? How could they be sure that a convenient Greek would turn up at the appropriate time for the abduction? And if it were intended as exculpation of Antiochus, the story should have had him break into the Temple to save the helpless captive from the fate imposed on him by wicked and bloodthirsty Jews whose evil conspiracy was foiled by the heroic king. That would be a splendid scenario in itself. Instead, the narrative has Antiochus completely unaware of the plight of the victim until he entered the Temple. And, if he did anything about it, the tale, as we have it, does not include the outcome. We doubtless do not have the full story, but in present form it would do little for Antiochus' reputation. ${ }^{18}$ Josephus has given us just enough to discredit the story and to discredit Apion in the process.

This tale hardly qualifies as an authentic reflection of ancient antisemitism. Its very absurdity undermines any effectiveness it might have had. Modern scholars have assiduously dissected it, finding a number of different motifs and excavating two separate compositions, one on the kidnapping and fattening of the victim for the kill, the other on a conspiracy to sacrifice a Greek in the Temple as part of Jewish hostility against all Greeks. Just how and when they were combined in a single version is beyond knowing. ${ }^{19}$ And further speculation would bear little fruit. The tale that Josephus transmits served the principal purpose of allowing the historian to shoot it full of holes with ease and with vitriol. Indeed he had a field day denouncing Apion for inventing a fanciful tale more akin to dramatic tragedy than to history, internally inconsistent, exaggerated to the point of being preposterous, and exhibiting either complete ignorance of Jewish institutions or contemptible malice in distorting them. ${ }^{20}$ Apion is the principal target and the concocted yarn a major stick with which Josephus could beat him. The ingenious deconstructions of the tale by modern scholars overlook or downplay the rhetorical character of Josephus' presentation here as elsewhere in the Contra Apionem. ${ }^{21}$

18 Josephus himself castigates the tale partly on this ground, pointing out caustically that it fails to acquit Antiochus of sacrilege as its creators planned because it has the king totally surprised upon discovering the captive in the Temple; C. Ap. 2.97: non tamen a sacrilegio privat Antiochum, sicut arbitrati sunt qui haec ad illius gratiam conscripserunt; non enim praesumpsit aliquid tale, ut ad templum accederet, sed sicut aiunt invenit non sperans.

19 Bickerman's ingenious reconstruction ("Ritualmord," 225-38) is the indispensable starting point for this view, accepted by most scholars; cf. Stern, Greek and Latin Authors, 412; Schäfer, Judeophobia, 62-65; Barclay, Flavius Josephus, 217-18. Building upon this, Bar-Kochva produced a more elaborate and overly complex construct, Image of the Jews, 263-71.

20 Josephus C. Ap. 2.97-111.

21 See Gruen, “Greeks and Jews,” 31-51. On Josephus' use of rhetoric generally in Contra Apionem, see J. W. van Henten and R. Abusch, "The Depiction of the Jews as Typhonians and 
That is not to say that Apion invented the tale out of whole cloth or that Josephus manufactured it simply to discredit the Alexandrian scholar. But it is well to remember that we have only a portion of the narrative, the portion that Josephus chose to provide, we lack the context in which it appeared in Apion's work, and we are left to guess what objectives he may have had in retailing it. Personal motivation may well have played a part. Apion, as a prominent Alexandrian intellectual, was chosen as member of a delegation to the Roman emperor Gaius in 40 C.E. to address the recent violence and upheaval among Greeks, Jews, and Egyptians in Alexandria. Jews sent a rival embassy to present their case, and the resultant clash provoked some nasty remarks by Apion, including the charge that Jews failed to pay adequate honors to the emperor. ${ }^{22}$ Friction between Jews and Greeks in Alexandria had issued in serious violence in 38 C.E., and Apion had evidently earned a reputation as a prime opponent of Jewish privileges in the city. It is not surprising that he might sponsor slanderous calumnies about his foes. ${ }^{23}$ The riots in Alexandria were dramatic and divisive, a logical prod for Apion's acrimony. That is not, however, equivalent to pagan antisemitism.

What deserves emphasis here is the noteworthy inference that Josephus made about the original authors of the blood libel. As we have seen, he identified the perpetrators as those who sought to stand up for Antiochus and to cover up the perfidy and sacrilege that he inflicted upon Jews for no other reason than that he needed to replenish his treasury. ${ }^{24}$ Never mind that this explanation may be fraudulent or mendacious. The fact that Josephus conveyed it is itself revealing. By pinning the blame on Seleucid propagandists endeavoring to justify Antiochus' expropriation of Temple funds, he sets the tale outside the category of antisemitism. Its authors had political motives, to rescue the reputation of the king, not a matter of ingrained prejudice against the nation. Most of Josephus' blasts against Apion concern his alleged errors, distortions, and ignorance,

Josephus' Strategy of Refutation in Contra Apionem," in Josephus' Contra Apionem: Studies in its Character and Context, ed. L. H. Feldman and J. R. Levison (Leiden: Brill, 1996), 271-309; S. Mason, "The Contra Apionem in Social and Literary Context: An Invitation to Judean Philosophy,” in Josephus' Contra Apionem: Studies in its Character and Context, ed. L. H. Feldman and J. R. Levison (Leiden: Brill, 1996), 187-228; R. G. Hall, "Josephus' Contra Apionem and Historical Inquiry in the Roman Rhetorical Schools," in Josephus' Contra Apionem: Studies in its Character and Context, ed. L. H. Feldman and J. R. Levison (Leiden: Brill, 1996), 229-49.

22 Josephus, Ant. 18.257-259.

23 Cf. Rives, "Human Sacrifice," 71.

24 Josephus, C. Ap. 2.90, quoted above, n. 16. 
not his prejudice against Jews. ${ }^{25}$ This so-called blood libel hardly stands as an exemplar of widespread anti-Judaism.

Was it indeed spread widely at all? We possess only one other instance of this slander. It appears in a very late source and is ascribed to an otherwise unknown author named Damocritus, whose date, nationality, and motivation evade inquiry. We are told only that he was a historian and that he wrote a book "On the Jews." From that work we are treated to just a single brief excerpt which parallels in small part the so-called blood libel in Apion. According to that quotation, Damocritus claimed that the Jews worship the golden head of an ass (an allegation also found in Apion), and that they hunt down and offer up (as a sacrifice) a foreigner every seven years, shred his flesh piece by piece and thus kill him. ${ }^{26}$ There is obvious overlap with Apion's narrative, but also differences, in that Damocritus has the ritual take place every seven years (an evident allusion to the Jewish sabbatical year) instead of annually, adds some grisly details about the manner of execution, and omits explicit reference to cannibalism. It is perfectly possible, even probable, that both stories derive from a single source, with each author spicing it up with his own lurid particulars. There need not have been two separate and independent traditions. ${ }^{27}$

What merits stress is that this constitutes the extent of our evidence on the "blood libel." It does not rear its ugly head elsewhere. It makes no appearance even in Tacitus' long list of hostile comments, even if many of them are ironic. ${ }^{28}$ He could have paraded the blood libel as prime exhibit of Jewish villainy or as an object of mockery, as his contemporary Josephus did. But he passes over it in silence. It is difficult to avoid the conclusion that the slander of Jews capturing, fattening, and sacrificing an innocent gentile had little or no traction in the pagan world. "Antisemitism" would be a misnomer.

25 Gruen, "Greeks and Jews," 45-47. Cf. Jones, "The Figure of Apion,” 305-7.

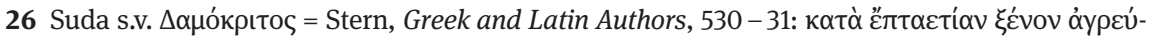

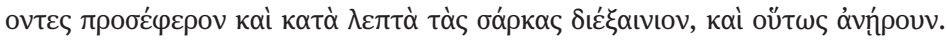

27 On the Damocritus story, see the cautious and sensible remarks of Barclay, Flavius Josephus, 217-18. Bar-Kochva, Image of the Jews, 259-63, employs Damocritus to fill in gaps in Apion's version and thus to piece together an original version, an ingenious but ultimately speculative task. The tale of worshipping the head of an ass also comes in different versions but constitutes a separate strand not directly pertinent here.

28 On Tacitean irony in his treatment of Jews, see E. S. Gruen, Rethinking the Other in Antiquity (Princeton: Princeton University Press, 2011), 179-96. 
A second comparably gruesome libel appears in a number of sources and seems to have earned greater attention: the identification of Jews with lepers, that is, persons of impure and disgusting characteristics. The earliest reference to that dubious designation comes from Manetho, the learned Egyptian scholar and priest, writing at the beginning of the third century B.C.E., who composed a three-volume work on the history of Egypt in Greek, which included the chronological division into thirty dynasties that remains the standard framework for Egyptian history to this very day. In the course of it, he had reason to remark on Jews who played a part in the ongoing story of the Egyptians. ${ }^{29}$ The three volumes, alas, do not survive, but two noteworthy extracts were preserved by Josephus who, as we have seen, was keen to refute slanders against his people. The first, an account of the invasion of Egypt and oppression of its inhabitants by the Hyksos, is largely irrelevant for our purposes. Josephus attempts to find an indirect link to the Jewish experience by concluding the tale with the eventual departure of the invaders (after five centuries!) to Syria where they built the city of Jerusalem. ${ }^{30}$ But there is nothing in Manetho's quoted text here that makes explicit reference to Jews.

The second extract from Manetho is a different matter. Josephus maintains that this one comes not from sober Egyptian priestly chronicles but from fictitious concoctions and hearsay delivering untrustworthy tales about Jews. ${ }^{31} \mathrm{He}$ introduces his summary of the narrative accusing Manetho of wrongly mixing up the Jews with a mob of Egyptian lepers and those with other maladies who were expelled from Egypt. ${ }^{32}$ Having impugned the tale in advance, Josephus proceeds to recount it as ascribed to Manetho. In brief, it has the Egyptian king Ameno-

29 On Manetho, see the important recent treatments of I. S. Moyer, Egypt and the Limits of Hellenism (Cambridge: Cambridge University Press, 2011), 84-141, and J. Dillery, Clio's Other Sons: Berossus and Manetho (Ann Arbor: University of Michigan Press, 2015), passim, especially viixxxiii, 301-47.

30 Josephus, C. Ap. 1.73-90. The reference to Jerusalem may be Josephus' own addition.

31 Josephus, C. Ap. 1.228-229. The complex question of where the boundary lies between the authentic text of Manetho and the spurious Ps. Manetho has received much discussion and needs no further treatment here. See the valuable summary of the issue with bibliography by Barclay, Flavius Josephus, 335-37. For present purposes no decision is required. See, more recently, the discussions of Moyer, Egypt and the Limits of Hellenism, 116-25; Dillery, Clio's Other Sons, 201-13. The second extract, whether or not it is genuine Manetho, does show that the leper libel was in circulation.

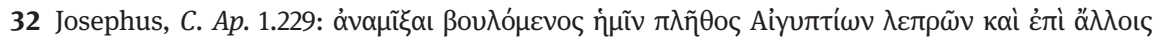

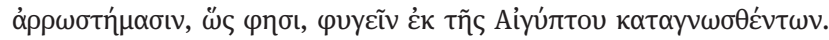


phis (an invented character, according to Josephus) express a desire to gain direct vision of the gods and was told that, in order to do so, he would have to purge the land of all lepers and other polluted people. The king proceeded to expel all such persons from Egypt and to herd them into the city of Avaris. The exiles, however, managed to organize themselves, selected a leader, a certain Osarsiph, and joined with shepherd peoples who had earlier been expelled from Egypt and settled in Jerusalem. The combined forces made a joint assault on Egypt, causing the king to gather all the sacred animals and a multitude of Egyptians and flee to Ethiopia. The triumphant invaders punctuated their victory by plundering the land, robbing and pillaging, and even using the very sanctuaries of the gods to roast the sacred animals, an unspeakable sacrilege. They ruled for an unspecified time until driven out by the former king, his son, and the forces that they had assembled. ${ }^{33}$ The most noteworthy item in that narrative is the statement that Osarsiph, leader of the lepers and the diseased, having been named for the god Osiris, changed his name to Moses. ${ }^{34}$

So did Manetho then lay the leper libel upon the Jews? It looks bad on the face of it. Manetho has been regarded by many scholars as the arch antisemite, purveyor of the purportedly polluted Jews, banished from the land, only to return under the murderous Moses, who, together with Jerusalemites, ravaged the countryside and wreaked havoc upon Egyptian towns, temples, and divinities. ${ }^{35}$

Yet the matter is not so simple. Manetho's account defies reductive analysis as sheer antisemitism. On closer inspection some serious reservations arise about Manetho's supposed animosity toward Jews. Jews in fact receive no mention in the text of Manetho as cited by Josephus. The lepers and other diseased persons whom he castigates are explicitly referred to as Egyptians. Josephus says simply that Manetho wished to mix the Jews up with that polluted crowd. ${ }^{36}$ When king Amenophis expelled lepers and others and sent them to the quarries, Manetho clearly identifies them as Egyptians, some even as Egyptian priests, who were now to be separated out from the rest of the Egyptians. ${ }^{37}$ To be

33 Josephus, C. Ap. $1.230-251$.

34 Josephus, C. Ap. 1.250.

35 So, e.g., Sevenster, Roots of Pagan Anti-Semitism, 186-88; Stern, Greek and Latin Authors, 64; C. Aziza, "L'utilisation polémique du recít de l'Exode chez les ecrivains alexandrins," Aufstieg und Niedergang der römischen Welt II.20.1 (1987): 54-55; D. Mendels, "The Polemical Character of Manetho's Aegyptiaca," Studia Hellenistica 30 (1990): 103-9; M. Pucci Ben Zeev, “The Reliability of Josephus Flavius: The Case of Hecataeus' and Manetho's Accounts of Jews and Judaism," Journal for the Study of Judaism 24, no. 2 (1993): 233.

36 Josephus, C. Ap. 1.229; quoted above, n. 32.

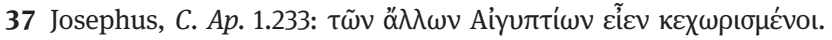


sure, their ranks were subsequently swelled by inhabitants of Jerusalem who joined in the retaliatory assault on Egypt. But Manetho refrains from calling them Jews and does not indict them as a nation. That would be excessive restraint if he were conducting an antisemitic campaign. The connection between Jews and lepers is made by Josephus and imputed to Manetho but does not appear in the latter's text. The sole link comes in the statement that Osarsiph changed his name to Moses. But that is a weak link indeed. Josephus tacks it on at the end of his quotation of Manetho, heading it with the notation "it is

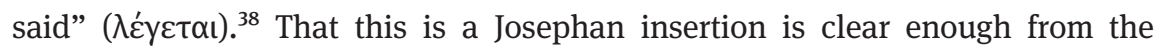
fact that he introduces Osarsiph here as if for the first time. In fact, however, he had already appeared in much the same words in Manetho's own text. ${ }^{39}$ It looks very much as if Josephus has fastened the leper libel upon Manetho, so as to have a handy target to shoot down. The motif of expulsion from Egypt of undesirable and contaminated persons had already enjoyed a long history in Egyptian literature, a frequent feature of texts that brand the enemy as sacrilegious and villainous ravagers until ejected by champions of the nation. ${ }^{40}$ It was not nurtured in antisemitic soil.

A variant on the narrative ascribed to Manetho appears in a fragment of another Egyptian intellectual fluent in Greek who composed a history of Egypt, Chaeremon, possibly identical with the Stoic philosopher of that name and a tutor of Nero, thus a figure of the early first century C.E. ${ }^{41}$ Chaeremon's version overlaps with that of Manetho but includes a number of aberrant details and discrepancies. He has Amenophis swing into action after the goddess Isis appeared to him in a dream and advised him, through a sacred scribe, to rid the country of its impure population, 250,000 of them, which he proceeded to do with an edict of banishment. Leadership of the exiles was taken by two sacred scribes named, interestingly enough, Moses and Joseph, both of whom also had Egyptian names. They subsequently joined forces with another 380,000 persons who had been left by the king at Pelusium on the Egyptian border and forbidden to enter the land. The combined peoples then invaded Egypt and caused Ameno-

38 Josephus, C. Ap. 1.250.

39 Josephus, C. Ap. 1.238. Rightly noted by A. J. Droge, "Josephus Between Greeks and Barbarians," in Josephus' Contra Apionem: Studies in its Character and Context, ed. L. H. Feldman and J. R. Levison (Leiden: Brill, 1996), 134-36; Schäfer, Judeophobia, 20.

40 See J. Yoyotte, “L'Égypte ancienne et les origines de l'antijudaïsme," Revue de l'histoire des religions 163 (1963): 133-43; D. B. Redford, Pharaonic King-lists, Annals and Day-books: A Contribution to the Study of the Egyptian Sense of History (Mississauga: Benben, 1986), 276-83.

41 See Stern, Greek and Latin Authors, 417-18; van der Horst, Chaeremon; Barclay, Flavius Josephus, 153. 
phis to flee to Ethiopia, from which he and his son would later reinvade and restore Egyptian rule. ${ }^{42}$ The parallels with Manetho's tale are palpable, although the divergences suggest a somewhat different tradition. Josephus links the two as comparable purveyors of narratives hostile to Jews. Yet even the abbreviated fragment that he chooses to quote, out of context, from a large history of Egypt, contains no explicit mention of Jews. We may be sure that if Chaeremon had mentioned them, Josephus would not have omitted it. Only the names Moses and Joseph hint at a Jewish connection, and both of them sport Egyptian names as well. Even the term "leper" does not surface in the Chaeremon fragment; Josephus has to introduce it in his criticism of Charemon's account. ${ }^{43}$ It is hard to escape the conclusion that the selection of this fragment had more to do with Josephus' agenda of knocking over straw men than of any vilification of Jews by the pagan author.

We can turn now to the irrepressible Apion. He too had something to say relevant to this subject. And the surviving remarks reveal once more the insidious selectivity of Josephus who reshapes the message for his own purposes. The quotation he supplies from Apion, once more snatched out of a context that we are not privy to, presents some peculiar and largely inexplicable remarks. Apion ascribes to Moses the institution of open-air prayer houses in each district of his home town Heliopolis, where he erected pillars instead of obelisks, and installed the relief of a boat evidently to serve as a sundial. ${ }^{44}$ Just what this means is largely opaque but not obviously hostile. Nevertheless, it caused Josephus to go on a rant. He ripped Apion for a whole range of errors, including the malicious suggestion that Moses carved a graven image, which, of course, no Hebrew would ever do. ${ }^{45}$ Probably not. But no pagan would be likely to complain about graven images, since they made them all the time. Josephus has once more distorted the intent of an author whom he wishes to use as a whipping boy. And where is there reference to Jews as lepers? Not in any quoted text of Apion. They appear only in Josephus' commentary on the text where he discusses the date of the Hebrews' exodus from Egypt which, according to him, Apion got wildly wrong. ${ }^{46}$ Here Josephus claims that Apion's account refers to an exodus of the lepers, the blind, and the lame under Moses' leadership. ${ }^{47}$ One need not infer that the des-

42 Josephus, C. Ap. 1.290-292.

43 Josephus, C. Ap. 1.298, 1.302.

44 Josephus, C. Ap. $2.10-11$. See the notes of Barclay, Flavius Josephus, 174-75.

45 Josephus, C. Ap. 2.12-14.

46 Josephus, C. Ap. 2.13-19.

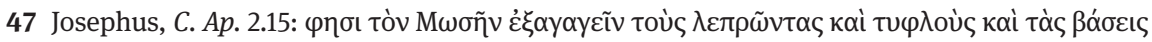

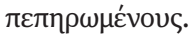


ignation as lepers actually represents Apion's wording or, if it did, that he made anything of it at all. Josephus blasts him for a host of inaccuracies, implausibilities, and fictive inventions. Jews as lepers were not among them. For Apion it was evidently a non-issue.

The leper libel does emerge more blatantly in a fuller and grimmer story ascribed to a certain Lysimachus. We know very little about him. Josephus chooses to provide no details, so we are ignorant of his date and provenance. ${ }^{48}$ For our purposes what matters is Lysimachus' connection of Jews with lepers expelled from Egypt which appears more unequivocal and more direct than what we found in Manetho or Apion. Or is it?

Lysimachus' exposition in brief summary, as we read it in Josephus, has the Jewish people, afflicted with leprosy, scabs, and other diseases, seek refuge in the temples, and since many persons contracted these sicknesses, one of the consequences was crop failure in Egypt. The situation prompted the king, named Bocchoris in this version, on advice of the god Ammon, to drive the impure and impious out of the shrines and into the desert and to drown those with scabs and leprosy, thereby to purify the sanctuaries. The latter were duly packed into lead sheets and sunk in the sea, the former left in the desert to die. But they were determined to survive and pleaded with gods to save them. Thus began the long trek under Moses until they reached inhabited territory. On Moses' instructions, they mistreated and abused the people, plundered and burned all the temples and altars they came across, and built their own city of Jerusalem. ${ }^{49}$ The account, in this form, is thoroughly hostile and the most graphic association of Jews with lepers and the diseased-not to mention identification with temple robbers and destroyers.

Yet even this tale carries ambiguity. The text does not lend itself as readily as the others to a dissection that separates reproduction of the original from Josephan intrusion. Here Josephus appears to engage in paraphrase rather than direct quotation. He is eager to lump Lysimachus with other writers, namely Chaeremon and Manetho, who spread lies about lepers and those scarred by disease, but he singles out Lysimachus as going beyond them in the incredibility of

48 Barclay, Flavius Josephus, 159, provides the essentials and the most important bibliography. Bar-Kochva, Image of the Jews, 307-16, 333-37, makes an extensive case for identifying Lysimachus with a Greek Alexandrian writer of the same name and places him in the later second century B.C.E. The argument for the date is not implausible, but it relies heavily on the presumption that Lysimachus' references to Jewish destruction of temples and altars reflects the actions of the Hasmoneans, a highly speculative proposition.

49 Josephus, C. Ap. 1.305-311. 
his inventions which grow out of deep animosity. ${ }^{50}$ Josephus has nicely set the stage-or rather loaded the dice. When he turns to the actual paraphrase of Lysimachus' text, matters are not quite so straightforward.

The Jewish people are indeed identified with those suffering from leprosy, scabs, and other diseases. ${ }^{51}$ But the infliction of punishment by king Bocchoris fell upon two separate groups. The first were the impure and impious ones who were driven out of the holy shrines and banished into the wilderness, the others, afflicted with leprosy and scabrous disease, were to be immediately drowned. ${ }^{52}$ But, of course, it was the wilderness goers, not the lepers, who went on to Judea, plundered temples, and established Jerusalem. So, were Jews lepers or not? Lysimachus introduced them as such, but his story then separated them from the leprous characters who were plunged into the sea. Either Lysimachus has been quite clumsy in his presentation or Josephus mangled it, whether inadvertently or deliberately. Scholars have detected two separate traditions or two layers of the tale awkwardly fitted together. ${ }^{53}$ The two groups of offenders, the impious and the leprous, stemmed from independent sources that were sewn together but whose seams are still showing. Whether Lysimachus or Josephus did the stitching, the confused result would not effectively advance the cause of labeling Jews as lepers.

The remainder of Lysimachus' story has Moses and his followers move resolutely through the wilderness, reach inhabited land, oppress the inhabitants, and destroy the religious shrines. As Josephus himself pointed out in his caustic criticism of Lysimachus, how could people who were in such bad shape manage to cross the desert, conquer the land, found a city, and build a great temple ${ }^{54}$ The criticism is valid, but the story's deficiencies may owe less to Lysimachus' failings than to Josephus' manipulation. And the leper libel carries little weight.

Its staying power, in fact, is rather questionable. A possible allusion to it occurs in the work of Pompeius Trogus, a Roman historian of Gallic extraction writing in Latin in the age of Augustus, an epitome of whose work is preserved by the much later and, to us, rather obscure intellectual Justin. Trogus' lengthy survey

50 Josephus, C. Ap. 1.304.

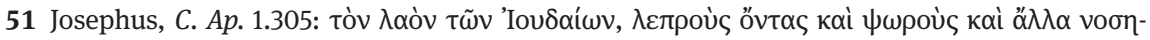

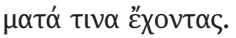

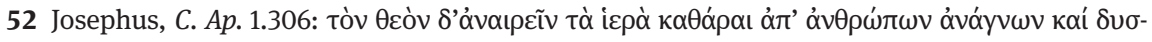

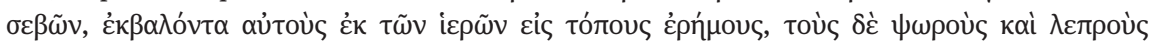

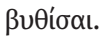

53 See Stern, Greek and Latin Authors, 385-86; Barclay, Flavius Josephus, 160; Bar-Kochva, Image of the Jews, $320-29$.

54 Josephus, C. Ap. 1.315, 1.318. 
of Greek, Hellenistic, and Roman history included a brief excursus on the Jews. His sketch has Jews originate from Damascus, but he has some slight awareness of biblical traditions, among them the Hebrews' sojourn in Egypt in the time of Joseph and Moses, even though he telescopes the generations by having Moses as son of Joseph. In the short narrative excerpted by Justin, Trogus does mention that Egyptians were afflicted with scabs and skin disease, with the result that Moses and others were driven out of Egypt so as to prevent further spread of this plague. ${ }^{55}$ Leprosy is not specified here, but scaly skin disease may imply it. More important, this notice does not appear in a text hostile to the Jews, nor is leprosy or its equivalent ascribed to them as some heinous component of their existence. Trogus' account has the afflicted expelled simply to contain the contamination, has Moses lead the exiles to their destination, and explains their subsequent preference for holding themselves apart by memory of the contagion and unwillingness to have a similar cause spoil relations with their neighbors. ${ }^{56}$ That is very different from an enduring leper libel.

The issue of Jewish isolationism and its connection with the taint of leprosy appears also in another source, the Greek historian Diodorus of Sicily, writing in the late first century B.C.E. Diodorus narrates the troubling tale of the siege of Jerusalem by the Seleucid king Antiochus VII Sidetes ca. 135 B.C.E. ${ }^{57}$ In Diodorus' account, when the besieged were prepared to capitulate, many of the king's friends urged him to take the city by force and utterly wipe out the race of the Jews because they alone of all nations held themselves apart, refusing to mingle with other peoples and regarded all as their enemies. The king's friends proceeded to underscore their point by reminding Antiochus that the ancestors of the Jews had been driven out of Egypt as men who were impious and hated by the gods. ${ }^{58}$ And they noted further that the expulsion targeted those who had white or leprous marks on their bodies, thus forced across the border as polluted persons, so as to purge the nation. ${ }^{59}$ The advisers of the king evidently drew upon hostile reports about the Jews and included a number of other vicious ru-

55 Justin, 36.2.12: Sed Aegyptii, cum scabiem et vitiliginem paterentur, responso moniti eum cum aegris, ne pestis ad plures serperet, terminis Aegypti pellunt. On Trogus' excursus on the Jews, see J. G. Gager, Moses in Greco-Roman Paganism (Nashville: Abingdon, 1972), 48-56.

56 Justin, 36.2.15: et quoniam metu contagionis pulsos se ab Aegypto meminerant, ne eadem causa invisi apud incolas forent, caverunt, ne cum peregrinis conviverent.

57 On the siege, see most recently K. Atkinson, A History of the Hasmonean State: Josephus and Beyond (London: Bloomsbury, 2016), 55-59.

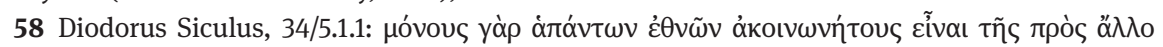

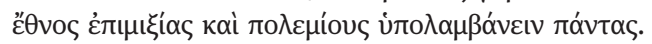

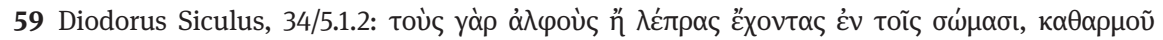

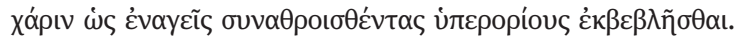


mors that might help persuade Antiochus Sidetes to eradicate the nation. ${ }^{60}$ How large a role did the leper libel play in their importuning and how central was it to their case? Very hard to say. What we do know, however, is that Antiochus rejected all their arguments, ended the siege, and absolved the Jews of the accusations leveled against them. ${ }^{61}$ In short, whatever significance the leper libel may have possessed amidst the welter of charges, it certainly did not carry the day. The slander was summarily dismissed. ${ }^{62}$

One last author picked up the tale of the Jews' expulsion from Egypt and made apparent allusion to the leper libel. The great Roman historian Tacitus at the end of the first century C.E. devoted a long excursus in his Histories to a discussion of Jewish practices, experiences, and characteristics, mostly with a cynical and jaundiced eye. ${ }^{63}$ He evidently had access to some of the variant traditions that appeared in authors like Manetho, Apion, Chaeremon, Lysimachus, and Trogus. Most writers agree, he observes, that a pestilence prompted the expulsion of the Jews from Egypt. He sets that event in the reign of Bocchoris on the advice of the oracle of Ammon, a close parallel to Lysimachus' version. As Tacitus reports it, when a plague broke out in Egypt which disfigured the body, Ammon instructed the king to purge his kingdom by ridding it of that race of men who were hateful to the gods. ${ }^{64}$ There followed the familiar story of Hebrews herded into the desert and then guided out of it by Moses. Here too the leper libel is there but quite muted. The term itself does not appear, although the "pestilence" that "disfigures bodies" can certainly lend itself to that interpretation. What stands out here, however, is that the allusion does not serve as a campaign of vilification against Jews. They are, to be sure, characterized as

60 Diodorus Siculus, 34/5.1.3-4.

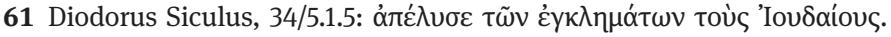

62 A closely similar story about the siege of Jerusalem is told by Josephus who gives a fuller version of the events but a briefer account of the king's advisers' efforts to press for genocide on the grounds of the Jews' alleged isolationism; Ant. 13.236-248. He makes no mention however, of the leper libel. The similarity of the two versions has induced many to postulate a common source, namely Posidonius of Apamea. But there are good reasons to question that conclusion. See Bar-Kochva, Image of the Jews, $440-57$.

63 See the extensive treatment by R. Bloch, Antike Vorstellungen vom Judentum: Der Judenexkurs des Tacitus im Rahmen der griechisch-römischen Ethnographie (Stuttgart: Franz Steiner Verlag, 2002). An analysis of Tacitean irony in this excursus may be found in Gruen, Rethinking the Other, 179-96.

64 Tacitus, Hist. 5.3.1: plurimi auctores consentiunt orta per Aegyptum tabe quae corpora foederat, regem Bocchorim adito Hammonis oraculo remedium petentem purgare regnum et id genus hominum ut invisum deis alias in terras avehere iussum. 
"hateful to the gods," but the gods in question are the Egyptian gods, not divinities whom the good Roman historian would have found admirable.

Moreover, Tacitus describes with admiration, whether begrudging or not, Moses' leadership in urging his flock, abandoned in dire straits by men and gods, to rely on their own resources which in fact served not only to get them through the desert but allowed them to conquer a land, found a city, and consecrate a temple. ${ }^{65}$ Whatever taint the scabrous body might have implied was heavily outweighed by the achievements of the people. Even the sardonic and scornful Tacitus refrained from fastening the leper libel on a banner of antisemitism. ${ }^{66}$

To conclude, this paper does not endeavor to whitewash pagan critics of Jews in antiquity. Suspicion, disdain, and antipathy toward Jews certainly did exist. Discomfort with their reclusiveness, mockery of their peculiar customs, misunderstanding of their religious beliefs, irritation with their ethnocentricity all played a role in marginalizing the Jews. Whether any of it rose to the level of antisemitism, however, is more questionable. This essay has fastened upon the two most malicious and pernicious charges leveled against Jews, the blood libel and the leper libel, and has endeavored to show that, troubling as they might seem, their impact and significance were far less consequential than is often realized. The accusation of human sacrifice makes only the rarest appearance in our texts and seems never to have caught on as a serious complaint. In its most virulent form, it owes more to the agenda of Josephus seeking to discredit its perpetrator than to any genuine conviction. The association of Jews with lepers and the unclean, although conveyed by more sources in diverse versions, emerges only in connection with the exodus from Egypt. And even there the tales are either manipulated by Josephus for his own ends, riddled with ambiguity, or too muted in significance to be effective means of defamation. None of them amounts to anything resembling what we might regard as genuine antisemitism. For those who seek models or precursors of contemporary expressions of racist hostility against Jews will not easily find them in antiquity. Tolerance was far more prevalent than persecution. It is time to stop hanging the wicked label of antisemitism upon the Greeks and the Romans-who already have enough wickedness to answer for.

65 Tacitus, Hist. 5.3.2-3. Gager (Moses, 127-28, and Origins of Anti-Semitism, 63-64) recognizes the positive features in the description of Moses but sees them as indicating the rebellious character of the Jews. Schäfer, Judeophobia, 31-33, sees only the negative aspects; similarly, Bloch, Antike Vorstellungen, 88-89; cf. Feldman, Jew and Gentile, 192-94.

66 We ignore here three brief later references to leprous spots on Moses. These are all derivative from the exodus story and have no pejorative connotation. See Gager, Moses, 129-32. 
Erich S. Gruen is Gladys Rehard Wood Professor of History and Classics Emeritus at the University of California, Berkeley. He is the author or editor of 16 books, more than 125 articles, and over 100 reviews in the areas of Roman History, Hellenistic History, and Second Temple Judaism. He is a member of the American Academy of Arts and Sciences, the American Philosophical Society, and an Honorary Member of the Roman Society of Great Britain.

\section{Bibliography}

Atkinson, Kenneth. A History of the Hasmonean State: Josephus and Beyond. London: Bloomsbury, 2016.

Aziza, Claude. "L'utilisation polémique du recít de l'Exode chez les ecrivains alexandrins." Aufstieg und Niedergang der römischen Welt II.20.1 (1987): 41-65.

Bar-Kochva, Bezalel. The Image of the Jews in Greek Literature: The Hellenistic Period. Berkeley: University of California Press, 2010.

Barclay, John M. G. Flavius Josephus: Against Apion. Volume 10 of Flavius Josephus: Translation and Commentary, edited by Steve Mason. Leiden: Brill, 2007.

Biale, David. Blood and Belief: The Circulation of a Symbol between Jews and Christians. Berkeley: University of California Press, 2007.

Bickerman, Elias. "Ritualmord und Eselskult: Ein Beitrag zur Geschichte antiker Publizistik." In Studies in Jewish and Christian History, edited by Elias Bickerman, 238-45. Leiden: Brill, 1980.

Bloch, René S. Antike Vorstellungen vom Judentum: Der Judenexkurs des Tacitus im Rahmen der griechisch-römischen Ethnographie. Stuttgart: Franz Steiner, 2002.

Chazan, Robert. From Anti-Judaism to Anti-Semitism. Cambridge: Cambridge University Press, 2016.

Cohen, Jeremy. "The Blood Libel in Solomon Ibn Verga's Shevet Yehudah." In Jewish Blood: Reality and Metaphor in History, Religion, and Culture, edited by Mitchell B. Hart, 116-35. New York: Routledge, 2009.

Daniel, Jerry L. "Anti-Semitism in the Hellenistic-Roman Period." Journal of Biblical Literature 98 (1979): 45-65.

de Lange, Nicholas. "The Origins of Anti-Semitism: Ancient Evidence and Modern Interpretations." In Anti-Semitism in Times of Crisis, edited by Sander L. Gilman and Steven T. Katz, 21-37. New York: New York University Press, 1991.

Dillery, John. Clio's Other Sons: Berossus and Manetho. Ann Arbor: University of Michigan Press, 2015.

Dillery, John. "Putting Him Back Together Again: Apion Historian, Apion Grammatikos." Classical Philology 98 (2003): 383-90.

Droge, Arthur J. “Josephus Between Greeks and Barbarians.” In Josephus' Contra Apionem: Studies in its Character and Context, edited by Louis H. Feldman and John R. Levison, 115 - 42. Leiden: Brill, 1996.

Droysen, Johann Gustav. Geschichte des Hellenismus. Munich: Oldenbourg, 1980.

Feldman, Louis H. Jew and Gentile in the Ancient World. Princeton: Princeton University Press, 1993. 
Feldman, Louis H. "Pro-Jewish Intimations in Anti-Jewish Remarks Cited in Josephus' Against Apion." Jewish Quarterly Review 78 (1988): 187-251.

Gager, John G. Moses in Greco-Roman Paganism. Nashville: Abingdon, 1972.

Gager, John G. The Origins of Anti-Semitism. Oxford: Oxford University Press, 1985.

Gaston, Lloyd. Paul and the Torah. Vancouver: University of British Columbia Press, 1987.

Gruen, Erich S. Constructs of Identity in Hellenistic Judaism: Essays on Early Jewish Literature. Berlin: De Guyter, 2016.

Gruen, Erich S. "Greeks and Jews: Mutual Misperceptions in Josephus' Contra Apionem." In Ancient Judaism in its Hellenistic Context, edited by Carol Bakhos, 31-51. Leiden: Brill, 2005.

Gruen, Erich S. Rethinking the Other in Antiquity. Princeton: Princeton University Press, 2011. Hall, Robert G. "Josephus' Contra Apionem and Historical Inquiry in the Roman Rhetorical Schools." In Josephus' Contra Apionem: Studies in its Character and Context, edited by Louis H. Feldman and John R. Levison, 229-49. Leiden: Brill, 1996.

Heinemann, Isaak. "Antisemitismus.” In Realencyclopädie der classischen Wissenschaft, edited by August Friedrich Pauly and Georg Wissowa, 5:3-43. Stuttgart: Metzler, 1931.

Heinemann, Isaak. "Ursprung und Wesen des Antisemitismus im Altertum.” In Festgabe zum zehnjährigen Bestehen der Akademie für die Wissenschaft des Judentums 1919-1929, edited by Akademie für die Wissenschaft des Judentums, 76-91. Berlin: Akademie-Verlag, 1929.

Hoffmann, Christhard. Juden und Judentum im Werk deutscher Althistoriker des 19. und 20. Jahrhunderts. Leiden: Brill, 1988.

Isaac, Benjamin. "The Ancient Mediterranean and the Pre-Christian Era." In Antisemitism: $A$ History, edited by Albert S. Lindemann and Richard S. Levy, 34-46. Oxford: Oxford University Press, 2010.

Isaac, Benjamin. The Invention of Racism in Classical Antiquity. Princeton: Princeton University Press, 2004.

Isaac, Benjamin. "Racism: A Rationalization of Prejudice in Greece and Rome." In The Origins of Racism in the West, edited by Miryam Eliav-Felden, Benjamin Isaac, and Joseph Ziegler, 32-56. Cambridge: Cambridge University Press, 2009.

Isaac, Jules. Genèse de l'Antisémitisme. Paris: Calmann-Lévy, 1956.

Isaac, Jules. Jésus et Israel. Paris: Fasquelle, 1948.

Jaeger, Werner. "Greeks and Jews: The First Greek Records of Jewish Religion and Civilization.” Journal of Religion 18 (1938): 137-43.

Jones, Kenneth R. "The Figure of Apion in Josephus' Contra Apionem." Journal for the Study of Judaism 36 (2005): 278-315.

Langmuir, Gavin I. Toward a Definition of Antisemitism. Berkeley: University of California Press, 1990.

Lindemann, Albert S. "The Jewish Question." In Antisemitism: A History, edited by Albert S. Lindemann and Richard S. Levy, 17-33. Oxford: Oxford University Press, 2010.

Mason, Steve. "The Contra Apionem in Social and Literary Context: An Invitation to Judean Philosophy." In Josephus' Contra Apionem: Studies in its Character and Context, edited by Louis H. Feldman and John R. Levison, 187-228. Leiden: Brill, 1996.

Mendels, Doron. “The Polemical Character of Manetho's Aegyptiaca." Studia Hellenistica 30 (1990): 103-9. 
Momigliano, Arnaldo. “J. G. Droysen Between Greeks and Jews.” In A. D. Momigliano Studies on Modern Scholarship, edited by G. W. Bowersock and T. J. Cornell, 147-61. Berkeley: University of California Press, 1994.

Mommsen, Theodor. Römische Geschichte III. Berlin: Weidmann, 1904.

Moyer, Ian S. Egypt and the Limits of Hellenism. Cambridge: Cambridge University Press, 2011. Nirenberg, David. Anti-Judaism: The Western Tradition. New York: W. W. Norton, 2013.

Pucci Ben Zeev, Miriam. "The Reliability of Josephus Flavius: The Case of Hecataeus' and Manetho's Accounts of Jews and Judaism." Journal for the Study of Judaism 24, no. 2 (1993): $215-34$.

Rebenich, Stefan. "Alte Geschichte in Demokratie und Diktatur: der Fall Helmut Berve." Chiron 31 (2001): 457-96.

Redford, D. B. Pharaonic King-lists, Annals and Day-books: A Contribution to the Study of the Egyptian Sense of History. Mississauga: Benben, 1986.

Rives, James. "Human Sacrifice among Pagans and Christians." Journal of Roman Studies 85 (1995): $65-85$.

Ruether, Rosemary Radford. Faith and Fratricide: The Theological Roots of Anti-Semitism. New York: Seabury, 1974.

Sanders, E. P. Paul and Palestinian Judaism: A Comparison of Patterns of Religion. Philadelphia: Fortress, 1977.

Sartre, Jean-Paul. Anti-Semite and Jew: An Exploration of the Etiology of Hate. Translated by George J. Becker. New York: Schocken Books, 1975.

Schäfer, Peter. Judeophobia: Attitudes toward the Jews in the Ancient World. Cambridge: Harvard University Press, 1993.

Schmitthenner, Walter. “Kennt die hellenistisch-römische Antike eine Judenfrage?” In Die Juden als Minderheit in der Geschichte, edited by Bernd Martin and Ernst Schulin, 9-29. Munich: Dt. Taschenbuch Verlag, 1981.

Schwartz, Daniel R. "Antisemitism and Other-isms in the Greco-Roman World." In Demonizing the Other: Antisemitism, Racism, and Xenophobia, edited by Robert S. Wistrich, 73-87. Amsterdam: Harwood Academic, 1999.

Sevenster, J. N. The Roots of Pagan Anti-Semitism in the Ancient World. Leiden: Brill, 1975.

Simon, Marcel. Verus Israel: A Study of the Relations between Christians and Jews in the Roman Empire (AD 135-425). Translated by H. McKeating. Oxford: Oxford University Press, 1986.

Stendahl, Krister. Paul Among Jews and Gentiles: And Other Essays. Philadelphia: Fortress, 1976. Voltaire. The Philosophy of History. New York: Vision, 1965.

van Henten, Jan Willem, and Ra'anan Abusch. "The Depiction of the Jews as Typhonians and Josephus' Strategy of Refutation in Contra Apionem." In Josephus' Contra Apionem: Studies in its Character and Context, edited by Louis H. Feldman and John R. Levison, 271-309. Leiden: Brill, 1996.

van der Horst, Pieter Willem. "Who was Apion?" In Japheth in the Tents of Shem: Studies on Jewish Hellenism in Antiquity, edited by James L. Kugel, 207-21. Leuven: Peeters, 2002.

Yavetz, Zvi. Judenfeindschaft in der Antike: Die Münchener Vorträge. Munich: Beck, 1997.

Yavetz, Zvi. “Judeophobia in Classical Antiquity: A Different Approach." Journal of Jewish Studies 44 (1993): 1-22.

Yoyotte, Jean. “L’Égypte ancienne et les origines de l'antijudaïsme." Revue de l'histoire des religions 163 (1963): 133-43. 
